\title{
«UN MAL PAÑO MUY VIEJO Y ROTO». FRANCISCO DE HERRERA EL MOZO Y LA REFORMA DE LA CAPILLA REAL DE SEVILLA
}

\author{
«UN MAL PAÑO MUY VIEJO Y ROTO». FRANCISCO DE \\ HERRERA THE YOUNGER AND THE REFORM OF THE \\ ROYAL CHAPEL OF SEVILLE
}

\author{
Antonio García BaEza \\ antonioleria@gmail.com
}

\begin{abstract}
Tras los fastos de la beatificación de Fernando III en 1671, el Cabildo de la Iglesia de Sevilla conmina a la monarquía a adecentar el frente de la Capilla Real para adecuarlo al nuevo culto. Tras distintas tentativas el encargo recae, por imposición regia, en manos de Francisco de Herrera el Mozo suponiendo, a la postre, su entrada definitiva en el entorno cortesano. Si bien la suntuosidad del diseño, su modernidad y la carestía económica supone la prolongación del proyecto en el tiempo y que el programa no pueda desarrollarse en toda su extensión.

Palabras clave: Diseño, orfebrería, retablo, Carlos II, Barroco
\end{abstract}

After the splendour of the beatification of Fernando III in 1671, the Council of the Church of Seville forces the monarchy to restore the front of the Royal Chapel in order to adapt it to the new cult. After several attempts, the task lies in the hands of Francisco de Herrera the Younger by royal imposition, a fact which finally allowed him to get into the court. However the sumptuousness of the design, its modernity and economic scarcity involves the extension of the project for a time, which means the programme cannot be developed in its full scope.

Keywords: Desing, yewelry, altarpiece, Carlos II, Barroco

En 1665, Mariana de Austria queda al frente de la Junta de Regencia a la que se encomienda el gobierno del reino durante la minoría de edad de Carlos II. Para hacer frente a los cuantiosos problemas económicos, bélicos y sociales que asolan a la población la Reina Madre cuenta con el validaje en la sombra del jesuita austríaco Johan Everhard Nithard, quien pronto sería expulsado de la Corte ante la poca simpatía que despierta entre la nobleza local. 
Continuando con la tradición del Rey Planeta, y por influencia del confesor regio, la Regente cuidaría en todo momento de aumentar el rito católico hispano como puntal de la legitimidad del joven monarca al frente de la Corona ${ }^{1}$. Un uso privativo de la propaganda fidei que cuenta con sus principales hitos en la consecución dogmática de la Inmaculada Concepción de María y en la canonización del rey Fernando III. Este último como cimiento de la monarquía católica local de la que el enfermizo monarca es legítimo heredero frente al bastardo Juan José de Austria y la deriva laicista de Luis XIV, el absolutista Roi Soleil.

Desde esta interesada posición no es de extrañar que, nada más concluir los conocidos fastos de la beatificación del Rey Conquistador en 16712 , la corona vuelva a insistir en el empeño de ver aumentada la veneración del nuevo justo hasta sus últimas consecuencias. Prebenda que obtiene poco más tarde de la Santa Sede, gracias a las gestiones del ya cardenal Nithard, con la universalización de su culto aprobada por la Sacra Congregación de los Ritos a través de su inclusión en el Martirologio Romano con fiesta y liturgia propia concretada el 30 de mayo, fecha del óbito ${ }^{3}$. Una deferencia eclesiástica que en la práctica supone su canonización de facto ${ }^{4}$.

En paralelo a la labor diplomática y bajo el mismo argumentario, la Regente retoma el interés por adecentar la situación del cuerpo incorrupto del conquistador -ahora reliquia santa-y de la estancia que lo preserva, llamada a convertirse

${ }^{1}$ Desde el inicio, el culto a Fernando III es dotado por la Corona y sostenido por la Catedral hispalense. Véase CINTAS DEL BOT, Adelaida: Iconografía del rey San Fernando en la pintura sevillana. Sevilla, 1991, pp. 23-24 y 29; MORALES, Alfredo J.: "Rey y santo. Ceremonial por Fernando III en la Catedral de Sevilla", en MÍNGUEZ, Víctor (ed.): Visiones de la monarquía hispánica. Valencia, 2007, pp. 89-101.

${ }^{2}$ Sobre la beatificación frente a la pretendida canonización, véase RUBIO MERINO, Pedro: "Fiestas de la Iglesia de Sevilla en la beatificación de San Fernando a través de los acuerdos del Cabildo Catedral: año 1671”, Memoria Ecclesiae, XXVI. Oviedo, 2005, p. 192.

3 1671, junio, 17. Sevilla. Cabildo ordinario. Archivo de la Catedral de Sevilla (ACS), Archivo Capitular, Secretaría, Autos Capitulares, lib. 71, f. 45: Los capitulares de Sevilla habían remitido a Roma un oficio propio de misas y rezos al monarca nada más concluir los fastos de la beatificación. 1672, octubre, 9. Sevilla. Cabildo extraordinario. ACS, Archivo Capitular, Secretaría, Autos Capitulares, lib. 71, f. 71: La noticia de su incursión en el martirologio romano fue trasmitida por Juan de Tejada de orden del Presidente del Consejo de Castilla, el Conde de Villaumbrosa.

${ }^{4}$ [Ca. 1671]. Sevilla. Por el santo rey don Fernando III de Castilla y León sobre que no es necesario canonizarlo con la nueva forma de canonización de los Decretos de la Santidad de Vrbano Octavo por estar canonizado en la forma y con la canonización que avía antes de los dichos decretos, y sólo se pretende que se declare no estar el Santo Rey ni la causa de su canonización en aquellos decretos comprehendida, y que se mande poner en el breviario y misal. ACS, Varios VIII, San Fernando, lib. 10.735: Según la comisión encargada de la canonización del Rey, no hay necesidad de proclamar su santidad si éste ya participa de la referencia litúrgica necesaria, porque la misma viene implícita. 
en nuevo centro de peregrinación y ámbito de exaltación de la monarquía. Un proceso que se hace eco de las históricas reivindicaciones de los canónigos y capitulares de la seo hispalense, y que la Reina encarga al Consejo de Castilla.

El último intento de remodelación de la Capilla Real se remonta a 1634, cuando se esperaba una inminente canonización que nunca llega a concretarse ${ }^{5}$. En aquel entonces, la estancia regia se encontraba muy necesitada «de toda la riqueza y veneración que se suele dar a los santos [...] pues la gran pobreza de la Capilla [...] no le ha podido dar más ornato que vn pedazo de paño de tela que cubre juntamente su cuerpo y el de los señores reyes don Alonso el Sauio y doña Beatriz, sin más vrnas ni sepulcros» ${ }^{6}$. De modo que, para paliar tan paupérrima situación, se propone la confección de un sepulcro-relicario «de plata, oro, metales y piedras de precio», cuya ejecución y materiales se tasan en 50.000 ducados.

Pero si bien este joyero nunca llega a concretarse, la mera intención de su hechura impulsa la transformación del presbiterio ${ }^{7}$ y la realización de un primitivo retablo mayor ${ }^{8}$, así como el remozado de la «basa y remate del tabernáculo antiguo de Nuestra Señora, que fue y es la tienda de campaña y capilla real, en cuya mansión regia esta santísima imagen de Nuestra Señora era la diosa de sus batallas y capitán general a quien el santo y señor Rey adoraba y llamaba su señora y consigo llebaba» ${ }^{9}$. Todo ello gracias a los recursos extraordinarios con los que Felipe IV favorece a la causa ${ }^{10}$.

Como hemos podido comprobar, hasta los prolegómenos de la beatificación, a fines de 1670, no vuelve a surgir con fuerza la preocupación por el indecoroso estado de la estancia. Y para entonces apenas se procura un ligero adecentamiento del tabernáculo central, lo que implica la reposición, limpieza y dorado

${ }^{5}$ Sobre la transformación de la Capilla Real entre 1634 y 1649, véase QUILES GARCÍA, Fernando: "En los cimientos de la Iglesia sevillana: Fernando III, rey y santo", Boletín del Museo e Instituto 'Camón Aznar', LXXV-LXXVI, 1999, pp. 217-218.

${ }^{6}$ [1634]. Sevilla. Memorial al Rey tocante a la beatificación del rey don Fernando, con cartas y papeles sobre el proceso. ACS, Varios VIII, San Fernando, legajo 10.735, f. [1]. Este documento ha sido citado con anterioridad por Quiles García ("En los cimientos...", op. cit., pp. 218 y 230) como pieza de los años setenta del siglo XVII. Si bien entendemos que se trata de una descripción paralela a los trabajos iniciados en 1634.

7 1634, agosto, 8. Sevilla. Carta de Luis Ortiz sobre el boceto de unas trazas para un tabernáculo de la urna del rey San Fernando. ACS, Varios VIII, San Fernando, legajo 10.735. [1634]. Sevilla. Memorial..., doc. cit.

${ }^{8}$ QUILES GARCÍA, Fernando: "En los cimientos...”, op. cit., p. 217, nota 74. Luis Ortiz de Vargas proyectó el retablo de la Virgen de los Reyes que fue elevado en la década de los cuarenta del siglo XVII y que sobrevivió toda la centuria.

9 1682, septiembre, 5. Sevilla. Capítulo. ACS, Capilla Real, Autos Capitulares, lib. 6, ff. 313v-314: Son los Marqueses de las Torres de la Presa quienes ayudan a este menester en 1635 .

${ }^{10}$ En el expediente octavo del legajo 10.739 del ACS se desarrolla cómo Felipe IV cede tres licencias de navíos procedentes de México para aplicarlo a la canonización, una cuantía que se reclama en 1677 a fin de utilizar la plata para la urna. 
de las chapas de plata con decoración de castillos, leones, entrepaños y rosas que forran el tabernáculo-sede del icono mariano y el perímetro que la circunda, llegando a envolver a las imágenes laterales de San Joaquín y Santa Ana. Una labor encomendada al platero Luis de Acosta ${ }^{11}$.

En consecuencia, cuando meses más tarde Juan Bonifaz ingenia la decoración efímera de la sala para los fastos de la beatificación -bajo la supervisión de los canónigos Gabriel Fontanar y Juan de Sagre Galindo- sólo queda a la vista el tabernáculo, libre de colgaduras ${ }^{12}$. De esta manera, las líneas generales del plan de actuaciones sobre el inmueble ya está trazado. De modo que la jubilosa coyuntura, antes que distraer el interés de los diputados y canónigos, sirve para reconducir la situación y remover el tablero a favor de la obra.

Nada más conocerse la noticia de la beatificación se inician los trámites para redefinir la cabecera de la Capilla, diferenciándose tres pasos en este proceso, a saber: primero se debe llevar a cabo la separación de los cuerpos regios; seguidamente, la creación de un sepulcro suntuario para la reliquia del monarca guerrero; y, finalmente, la elevación de un retablo en el que deben tener cabida la urna y el tabernáculo de la Virgen de los Reyes. Siendo imprescindible, en todo momento, la colaboración política, logística y financiera de la monarquía y sus administraciones.

11 1670, noviembre, 3. Sevilla. Capitulo. ACS, Capilla Real, Autos Capitulares, lib. 6, f. 1: «El espaldar de la silla donde está sentada Nuestra Señora ay clavadas y puestas setenta y seis castillas y leones con sus interpaos y rosas que le correseponden a la obra cabal y cerrada. En la tumbilla y tabernáculo donde está colocada nuestra sepora ay puestas y clvadas trescientas y sinquenta castillas y leones pequeñas que guarneçen la dicha tumbilla y tabernáculo por dentro y por fuera, con molduras de plata blanca y todos los arcos de dentro y de fuera cubiertos de oja de plata de martillo, blanca y bruñida. En la frente de la tumbilla del tabernáculo está clavada vna rosa grande de plata blanca y bruñida, y enciama vna celosía de plata dorada y calada. En medio del cielo de la tumbilla y tabernáculo, por la parte de dentro del, está vn engaste de plata dorado con vna piedra grande berde a modo de esmeralda. Quatro baras de plata blanca con sus cañones y capiteles y pedestales dorados y çincelados que dierran y sustentan el tabernáculo». Para Alfonso Pleguezuelo, este tabernáculo argénteo se incorpora a todos los diseños de posibles retablos de la Virgen de los Reyes y se conserva intacto en la actualidad debido a que fue, según palabras de Rodríguez de Quesada, «la tienda de capaña en que puso a esta soberana reina el Santo Rey» (PLEGUEZUELO HERNÁNDEZ, Alfonso: "Un proyecto de Bernardo Simón de Pineda para el retablo mayor de la Capilla Real de Sevilla”, Boletín del Seminario de Estudios de Arte y Arqueología, 47, 1981, p. 338).

12 1635, junio, 16 - 1687, enero, 12. Sevilla. Cuenta de maravedís de plata y vellón que han entrado en la caja de los depósitos de esta Santa Iglesia para la beatificación y canonización del santo rey San Fernando desde el año de 1635. ACS, Varios VIII, San Fernando, legajo 10.739, expediente 11, f. 86v: Juan Bonifaz percibe por el montaje un total de 34.000 maravedís de plata según se desprende de la libranza de 20 de abril de 1671 dispuesta a su nombre. Del montaje de la beatificación en la Capilla Real, existen noticias concretas en las actas capitulares de 14 de marzo y 6 y 7 de abril (1670-1682. Sevilla. Autos..., doc. cit., ff. 5-6v). 
A tal fin, las relaciones institucionales entre la Corte y la Iglesia de Sevilla comienzan a fluir con mayor celeridad, multiplicándose el número de representantes que intermedian entre ambas entidades. Algunos de estos interlocutores son fruto del ofrecimiento personal, como el marqués de Castromonte y Robledo cuando es nombrado mayordomo real ${ }^{13}$. Mientras que otros, los más, son comisionados para causas particulares, como Juan González Calderón, agente seglar para pleitos y negocios cortesanos ${ }^{14}$. Si bien el principal delegado y gestor del proyecto desde sus primeros pasos es el canónigo Juan de Tejada y Aldrete, administrador del Hospital Real' ${ }^{15}$, quien hace las veces de bisagra entre la Cámara y los cabildos a través de la Diputación del Santo Rey ${ }^{16}$. Siendo, a nuestro entender, el 'anónimo personaje' al que Heliodoro Sancho Corbacho alude como urdidor de todo el proceso de reparación de la Capilla Real ${ }^{17}$.

Esta nueva y definitiva andadura da comienzo el 8 de abril de 1671, y se prolongará por más de medio siglo. En esta jornada, la Diputación del Santo Rey -creada ad hoc en el seno de la sede de la Iglesia hispalense para llevar todas las gestiones relativas al proceso de canonización- presenta ante el Cabildo de canónigos los planos que, bajo sus propias indicaciones, realiza el capitán e ingeniero Francisco Ruesta - piloto mayor de la Casa de la Contratación y experto en medición naval y poliorcética-. «El vno de la Capilla Real como oy está, y el otro del sitio y forma en que se puede colocar con maior eleuación su santo cuerpo». Disponiendo en ambas trazas las líneas generales de todo planteamiento posterior ${ }^{18}$. Una propuesta que encuentra buena acogida entre los reverendos sevillanos, quienes, acto seguido, ordenan el pago de un emolumento de 34.000 maravedís al capitán a costa de la Hacienda del Santo Rey y la remisión de los planos a la Corte para su aprobación ${ }^{19}$.

${ }^{13}$ 1672, octubre, 3. Sevilla. Cabildo ordinario. ACS, Archivo Capitular, Secretaría, Autos Capitulares, lib. 71, ff. 67-67v.

14 1671, septiembre, 7. Sevilla. Cabildo ordinario. ACS, Archivo Capitular, Secretaría, Autos Capitulares, lib. 71, f. 65.

15 RUBIO MERINO, Pedro: "Fiestas...", op. cit., p. 193.

16 1671, marzo, 20. Sevilla. Cabildo extraordinario. ACS, Fondo Archivo Capitular, Secretaría, Autos Capitulares, lib. 71, f. 17: «don Juan de Texada, canónigo <emisario> en Madrid a la solicitud de los medios para la canonización del santo rey don Fernando y colocación de su santo cuerpo». Un papel oficial refrendado en: 1671, mayo, 13. Sevilla. Cabildo ordinario. ACS, Archivo Capitular, Secretaría, Autos Capitulares, lib. 71, f. 33v.

17 SANCHO CORBACHO, Heliodoro: "Historia de la construcción de la urna de plata que contiene los restos de San Fernando", Estudios de Arte Sevillano, núm. extraordinario del Boletín de Bellas Artes, 2a época, 1973, p. 96.

18 1671, abril, 8. Sevilla. Cabildo ordinario. ACS, Archivo Capitular, Secretaría, Autos Capitulares, lib. 71, f. 22v. Heliodoro Sancho Corbacho («Historia...», op, cit., p. 96) confunde el diseño de Francisco Ruesta con el concurso realizado con posterioridad en la Corte.

19 1635, junio, 16-1687, enero, 12. Sevilla. Cuenta ..., doc. cit., f. 86v.: Juan Bonifaz recibe el libramiento para pagar a Francisco Ruesta por los planos. 1671, abril, 14. Sevilla. 
Tejada recibe en Madrid esta documentación junto con las trazas el lunes 27 de abril a la una de la tarde, mismo día y hora en que el Consejo de la Cámara de Castilla se reúne para disponer que veía «bien encaminada la materia» del nuevo decoro que se pretende para la regia cabecera. Por lo que el canónigo hubo de esperar al anochecer para mostrar los planos al presidente de Castilla, que mandó extenderlos y disponerlos sobre bastidores para «comprehenderlos con facilidad». A continuación, el sacerdote se presentó ante Juan Lucas Cortés y Andrés Delgado -que posteriormente participarían en la aprobación del proyecto-, quienes pudieron contemplar con dedicación las trazas, calificándolas de excelentes, y tasando su ejecución en unos mil reales de plata ${ }^{20}$.

Habrá que esperar una semana para que el presidente del Consejo de Castilla y los miembros de su cámara pudieran admirar con detenimiento las plantas de Ruesta, escogiendo y rubricando las trazas numeradas como ocho y diez, correspondientes al retablo y a la urna respectivamente. No obstante, apostillarían que estos trabajos no deben tomarse como diseños acabados, sino como puntos de partida para nuevos proyectos más precisos que han de procurarse entre los artistas más próximos al gusto palaciego. Además, los nobles puntualizan ciertos cambios formales de los que hicieron observación, a saber: que el remate del sepulcro se peralte con respecto a la forma prevista porque la coronación propuesta resulta chata y pobre, procurándose mayor adorno y la realización de una imagen del Santo, y no la espada y la corona real previstas como alegoría del bienaventurado, «porque ya no era tiempo de simulacros». Que en el retablo se troquen las imágenes diseñadas de San Pedro y San Pablo por las de San Isidoro y San Leandro. Y, finalmente, que la Theotokos se eleve más dentro de la hornacina a fin de conservar el «tabernáculo antiguo de plata» ${ }^{21}$.

La propia Regente, interpelada desde Sevilla, dispone que para «la colocación del santo cuerpo se haga luego una vrna de plata con estremos dorados, muy rica», cuyo diseño debe ser de su agrado, del de la Cámara y de la curia hispalense, debiéndose procurar continuos informes y pareceres del prelado, el Cabildo de canónigos, el visitador y los capellanes reales con objeto de consensuar cada paso

Cabildo extraordinario. ACS, Archivo Capitular, Secretaría, Autos Capitulares, lib. 71, f. 25 (este último documento fue recogido previamente en QUILES GARCÍA, Fernando: "En los cimientos...", op. cit., p. 219, nota 80).

20 1671, abril, 28. Madrid. Carta de Juan de Tejada a la Diputación del Santo Rey sobre su llegada a la Corte. ACS, Varios VIII, San Fernando, legajo 10.739, expediente 9 (recogido previamente en SANCHO CORBACHO, Heliodoro: "Historia...", op. cit., pp. 97-100).

${ }^{21}$ [1671, octubre]. Madrid. Informe de Juan de Tejada que acompaña a diseños de urna y retablo remitidos a la Diputación del Santo Rey. ACS, Varios VIII, San Fernando, legajo 10.735, ff. [1]-[1v] (recogido previamente en QUILES GARCÍA, Fernando: "En los cimientos...”, op. cit., p. 219, nota, 80). 
que se dé22. Un acto acertado por lo que supone de implicación interinstitucional, pero que en la práctica conlleva la ralentización del proceso, pues, al dejar el desarrollo de la actividad en manos del interés particular de cada una de las partes, éste no será común siempre.

Los capitulares, «en el ínterin que se dispone la colocaçión < del cuerpo del Santo> con más ornato y grandeza a su memoria y fervorosa deuoción», proponen iniciar el adecentamiento de la Capilla con la separación de los cuerpos regios, ponderando la reubicación de Alfonso X y Beatriz de Suabia en los arcosolios de la entrada, «bien eleuados de el suelo y labrados de primor su arquitectura» ${ }^{23}$. Concretamente, al Rey Sabio le correspondería el muro de la epístola, «en aquel nicho que seruía el día de San Clemente de poner las efigies para el entrego de la espada», y a su progenitora el frontero ${ }^{24}$. Mientras que la reliquia del conquistador se mantendría en el centro de la sala, sobre el podio que históricamente lo viene recogiendo. Finalmente, los presbíteros disponen la posibilidad de adaptar este espacio como presbiterio bajo a fin de poder llevar a cabo actos litúrgicos, para lo cual se hace necesario recrecer el pedestal del sepulcro e ingeniar una puerta en el barandal que cierra el perímetro ${ }^{25}$.

A fines de año, todo parece bien encaminado. Juan de Tejada se encarga de seleccionar en la villa del Manzanares a los profesionales que concurren al concurso de las trazas del retablo-tabernáculo y la urna-relicario. Para la ocasión escoge, según indicaciones del propio sacerdote, a «vn arquitecto mui bueno que es Gregorio Terán, que también es ecultor, el qual hizo dos diseños para vrnas [...] y otro para adorno del altar. También hizo otro diseño Damián Surreño, platero de los de más opinión, que como la vrna a de ser de plata me pareçió a propósito. $<\mathrm{Y}>$ también hizo otro diseño Juan Asensio, pintor y architecto» ${ }^{26}$.

Pero el sacerdote aún guarda un último as en la manga. Un nombre que satisfaría tanto las necesidades cortesanas como las del Cabildo Eclesiástico al que representa. "Estando en este cuidado y no llenándome quanto se hazía busqué a don Francisco de Herrera, maestro seuillano, a quien partiçipé el estado de todo lo

${ }_{22}^{2}$ [1671, mayo, 5]. Madrid. Carta de Juan de Tejada dando cuenta al Deán y Cabildo de la Catedral de Sevilla sobre las consultas hechas a la Reina. ACS, Varios VIII, San Fernando, legajo 10.739, expediente 9; 1671, mayo, 20. Cédula de la Reina en que resuelve realizar una urna de plata y encarga sus diseños (recogido de SANCHO CORBACHO, Heliodoro: "Historia...", op. cit., p. 115, y QUILES GARCÍA, Fernando: "En los cimientos...", op. cit., p. 220).

${ }^{23}$ [1671, mayo-octubre]. Sevilla. Bosquejo de carta de la Capilla Real de Sevilla a la Regente a propósito de la urna de San Fernando y la conveniencia de separar los cuerpos reales. ACS, Varios VIII, San Fernando, legajo 10.739, expediente 9, [s.f.].

${ }^{24}$ [1671, octubre]. Madrid. Informe de Juan de Tejada que acompaña a los diseños remitidos a la Diputación del Santo Rey. ACS, Varios VIII, San Fernando, legajo 10.735, f. [1].

${ }^{25}$ [1671, mayo-octubre]. Sevilla. Bosquejo..., doc. cit., [s.f.].

26 [1671, octubre]. Madrid. Informe..., doc. cit., f. [1v]. 
referido y nuestro yntento para que hiciese dos diseños, vno para la vrna y otro para el altar. Ofreçiolos hazer con mucho gusto, y así lo ejecutó sin perder tiempo» ${ }^{27}$. Sevillano, pintor y diseñador afamado, bien posicionado en la Corte, del agrado de la Regente y resolutivo. Sin duda, Herrera parte con ventaja en esta carrera.

Una vez la Cámara de Castilla, el duque del Infantado, la Reina y otros «muchos señores de buen gusto» testan las propuestas procuradas por el canónigo, los diseños se remiten a Sevilla para su consenso ${ }^{28}$. El 3 de noviembre Jerónimo de Aranda y Guzmán - arcediano de Sevilla, canónigo de su Iglesia y capellán mayor de la Capilla Real- parte de la villa de Madrid hacia la ciudad del Guadalquivir portando un baúl con los dibujos y las cédulas reales que contienen los términos en los que se debe tramitar el proceso de selección ${ }^{29}$. Un ejercicio vacuo dado que los diseños del Mozo ya venían señalados desde Palacio como los que «su magestad manda ejecutar» porque le «pareçieron muy bien y los alabó mucho» ${ }^{30}$. Aún más, por si quedara algún atisbo de duda, Tejada adjunta a la misiva un informe de puño y letra del propio pintor sevillano escrito «para inteligencia de sus diseños ${ }^{31}$. Pero a pesar de todas estas directrices, como la selección se pretende consensuada, se apela en todo momento al parecer de todos los implicados para oficializar lo ya conocido.

Los canónigos, en cabildo ordinario de 20 de noviembre, dan cuenta de la llegada de «los diseños aprobados por el Consejo de la Cámara [...] para la colocación del cuerpo del Santo Rey y adorno del altar de Nuestra Señora de los Reyes»y, con ellos, de la cédula que les advierte que, «vistos los dichos diseños, haga que los reconoscan los artifices que fueren de mayor satisfación y, reconocidos, declaren el coste que podrá tener la dicha obra. Y, llegando el caso de ponerlos en execución, qué artífices o architectos serán más a propósito para encargársela y en qué tiempo se podrá acabar». A lo que la institución responde favorablemente y acuerda colegiar al arcediano de Niebla, como miembro más antiguo de la Diputación del Santo Rey, para entablar futuras conversaciones sobre estos asuntos con el prelado

${ }^{27}$ Ibídem.

${ }^{28}$ [1671, octubre]. Madrid. Informe..., doc. cit., f. [1v]. Según Sancho Corbacho ("Historia...", op. cit., p. 115) en el archivo catedralicio se conservaba una cédula de la Reina a los capellanes reales donde se expresa el envío de los diseños y su obligación de seleccionar el más acorde, el cual no hemos encontrado.

29 1671, noviembre, 3. Madrid. Carta de Juan de Tejada a la Diputación del Santo Rey sobre el envío de los diseños desde la Corte. ACS, Varios VIII, San Fernando, legajo 10.739, expediente 9. Incluye dos bosquejos, sin fechar, referidos a los trámites de Juan de Tejada previos a esta misiva que expresan el interés de la Diputación por los artistas invitados para el diseño e, igualmente, porque procure excusar al Cabildo de hacer cualquier gasto considerable al respecto de esta obra.

${ }^{30}$ [1671, octubre]. Madrid. Informe..., doc. cit., f. [1v].

31 1671, noviembre, 3. Madrid. Carta..., doc. cit. 
hispalense, con la propia Capilla y con el oidor de la Real Audiencia y visitador de la Capilla Real, Miguel de Arontegui y Echazarreta ${ }^{32}$.

Las propuestas que llegan de Madrid responden a la planimetría inicial de Ruesta. Todas contemplan una reestructuración del presbiterio y la elevación de un único retablo que contiene el tabernáculo mariano y el arca del Santo ${ }^{33}$. Una única pieza central en la que se deben focalizar todos los usos de la capilla: santuario, relicario, panteón real y centro simbólico de la fe local.

Bajo estas premisas, Herrera esboza su primer proyecto contemplando la posibilidad de elevar un retablo pétreo, posiblemente de mármoles, con alternancia de jaspes polícromos y piezas ornamentales de bronce ${ }^{34}$-al modo escurialenseal que se adosa el sepulcro con los restos del bienaventurado. Según sus propias acotaciones, la traza concebida parte del problema que supone la falta de espacio reservado en el frente de la estancia para un mueble de estas características. Viéndose obligado a adaptar sus planteamientos iniciales al encorsetado marco arquitectónico preexistente y al reducido recorrido del presbiterio.

La solución ideada pasa por disponer una construcción constreñida al arcosolio de la cabecera cuya parte inferior estaría enrasada a la superficie mural, ganando cuerpo y vuelo conforme se eleva en altura. Para ello, contempla el uso novedoso del estípite como principal elemento estructural y decorativo que sirve de transición entre los distintos ámbitos del mueble ${ }^{35}$. De modo que, mientras Ruesta proponía el uso de columnas áticas por la planitud de sus facciones, el Mozo da muestras de su conocimiento teórico apostando por un soporte prácticamente ignoto en la Península. Una decisión que se ve obligado a justificar técnicamente «por ser, avn por sus

32 1671, noviembre, 20. Sevilla. Cabildo ordinario. ACS, Archivo Capitular, Secretaría, Autos Capitulares, lib. 71, f. 83. [1672, enero, 10]. Sevilla. Esbozo de la carta de la Capilla Real de Sevilla dando cuenta de su aprobación de las trazas de Francisco de Herrera. ACS, Varios VIII, San Fernando, legajo 10.739, expediente 1. Por este bosquejo, conocemos que las cédulas de la Regente fueron remitidas a las cuatro partes interesadas el 22 de septiembre de 1671 .

${ }^{33}$ 1671, noviembre, 10. Madrid. Carta de Juan de Tejada a la Diputación del Santo Rey remitiendo los planos de Francisco Ruesta que por olvido se habian quedado atrás y que se estiman necesarios para la elección de los diseños. ACS, Varios VIII, San Fernando, legajo 10.739, expediente 13 (recogido previamente en QUILES GARCÍA, Fernando: "En los cimientos...”, op. cit., p. 222, nota 101). 1677, agosto, 10. Sevilla. Capítulo. ACS, Capi1la Real, Autos Capitulares, lib. 6, ff. 143v-144: Ya con anterioridad el retablo de la Virgen de los Reyes servía de relicario, si bien no tan explícitamente, ya que encerraba en su interior una alhacena «donde se guarda el cuerpo del señor San Leandro y <la> espada del Rey» cuyas llaves custodiaban las manos del Arzobispo y del Presidente de la Capilla.

${ }^{34}$ [1671, octubre]. Madrid. Informe..., doc. cit., f. [2v].

35 1671, octubre, 30. Madrid. Informe de Francisco de Herrera a la Diputación del Santo Rey sobre sus trazas. ACS, Varios VIII, San Fernando, legajo 10.739, expediente 3 (recogido previamente en SANCHO CORBACHO, Heliodoro: "Historia...”, op. cit., pp. 100-102). 
ymóscapos, de casi ningún relieue, $<\mathrm{y}>$ por poder dar sitio a las estatuas y sus repizas, las quales atisonan en el pedestal». Y es que el sinuoso relieve de este elemento constructivo sui generis, según mantiene, le permite jugar con su desarrollo tanto hacia el exterior como al interior. Proponiendo para la ocasión el uso de estípites, compuestos también por basamentos de gran planitud que apenas rebasan el grueso de los muros de la cabecera, y fustes que se elevan «arrimándose con el chapado a el muro sin más resalto que el poco que le tocare a el pedestal de la pilastra» ${ }^{36}$.

Cabe puntualizar que la estricta explicación de Herrera a los comitentes no es baladí, más si consideramos de que se trata de la primera descripción hispana conocida de un estípite, adelantándose dos décadas a su introducción definitiva por Benito Churriguera en el catafalco de la Reina María Luisa (1689) ${ }^{37}$. Un hecho lógico y nada casual habida cuenta que el diseñador hispalense será una de las fuentes ulteriores de las que vendrá a beber el churrigueresco ${ }^{38}$. Y es que, si bien es cierto que con anterioridad se había utilizado el soporte de manera esporádica en territorio hispano mediante su despojada versión manierista -como una pilastra troncocónica básica-, hasta el momento no se había descrito con tanta rotundidad y en versión tan evolucionada. Un conocimiento que parece emanar de la contemplación directa de grabados germanos y de la lectura detenida de la tratadística, principalmente de Wendel Dietterlin a través de Architectura: Von Außtheilung, Symmetria und Proportion der Fünff Seulen $(1594)^{39}$.

La propuesta del maestro sevillano contempla un único cuerpo de importantes dimensiones, recorrido por tres calles separadas por estípites de orden gigante. La zona central se reserva al tabernáculo de la titular - que está obligado a mantener por su carácter histórico-simbólico- y las laterales para los santos obispos

${ }^{36}$ 1671, octubre, 30. Madrid. Informe..., doc. cit., f. [1].

${ }^{37}$ Existen pocos precedentes de estípites en la Península y, en todo caso, vienen a ser dispuestos bajo un sentido decorativo extravagante. Es el caso de los de Cristóbal de Medina en la segunda planta del túmulo elevado en Málaga por la muerte del príncipe Baltasar Carlos en 1646. Véase ESCALERA PÉREZ, Reyes: "Vestir la arquitectura: fiesta barroca y dibujo de arte efímero en Andalucía", en AA. VV. Dibujos y ornamentos: Trazas y dibujos de artes decorativas entre Portugal, España, Italia, Malta y Grecia. Córdoba, 2015, pp. 182-183, fig. 7.

38 Sobre la unión de Herrera el Mozo y los orígenes de la familia Churriguera en Madrid véase GARCÍA BELLIDO, Antonio: "Estudios del Barroco español: Avances para una monografía de los Churrigueras", Archivo Español de Arte y Arqueología, tomo V. Madrid, 1929, pp. 51-55 y 79; RODRÍGUEZ GUTIÉRREZ DE CEBALLOS, Alfonso: Los Churriguera. Madrid, 1971, p. 17; GARCÍA BAEZA, Antonio. La polifacética figura de Francisco de Herrera Inestrosa, el Mozo (Tesis Doctoral Inédita). Sevilla, 2016, pp. 372382.

${ }^{39}$ Sobre la introducción del estípite en el reino de Sevilla, véase HERRERA GARCÍA, Francisco: «V. El retablo de estípites a lo largo de la primera mitad del XVIII», en HALCÓN ÁlVAREZ-OSSORIO, Fátima; HERRERA GARCÍA, Francisco; RECIO MIR, Álvaro: El retablo sevillano: Desde los orígenes a la actualidad. Sevilla, 2009, pp. 298-304. 
sevillanos apeados sobre repisas. Todo ello asentado sobre un banco de importante altura y gran planitud, apenas animado por los leves entrantes de las basas de los estípites. La predela vendría antecedida por la mesa de altar sobre la que reposaría el sepulcro. Mientras que sobre el cuerpo principal se dispone un entablamento movido con cornisa volada que sirve de elemento de transición con el arcosolio historiado que debió contemplarse como remate -aunque este último elemento no queda reflejado con claridad en la documentación-. Un juego de entrantes y salientes que multiplica el claroscuro de la policromía de los mármoles avivando el juego arquitectónico a fin de desmarcarse de la planitud del muro.

Premisas todas ellas paralelas a las que podemos contemplar en el diseño que realiza dos años más tarde para el retablo mayor del Hospital de los Aragoneses de Madrid $^{40}$ y que, pensamos, son constantes a lo largo de su conocida faceta retablística $^{41}$. Un modo de componer novedoso, pero heredero tanto de los cánones de Alonso Cano -a base de un único cuerpo central articulado por columnas de orden gigante que proporcionan verticalidad, solemnidad y permiten focalizar toda la atención sobre el motivo devocional central ${ }^{42}$ - como de las obras realizadas por Pedro de la Torre y Sebastián Herrera Barnuevo en la capital desde mediados de siglo.

La arquitectura se convierte en la protagonista del diseño del mueble, estando desprovista de más decoración. «La razón de gastar miembros lisos y grandes -dice Francisco de Herrera- es propio de la arquitectura de piedra. Lo vno por no tener el manejo de la madera, lo otro por el poderse pulir, que es la hermosura de la piedra. $Y$ así no es neçesario aduertir que no me e valido de entellones ni agallones encontrados y otras chucherías <dado> que estas son buenas $<$ sólo> para la madera $\rangle^{43}$.

En contraste con la pretendida sencillez teatral del retablo, el diseño de la caja fúnebre se convierte en pura ornamentación. Para su composición, el pintor parte del volumen y el perfil irregular del ataúd original que debe contener. «La caxa del cuerpo del Santo Rey tiene dos pies de alto y seis de largo, y dado caso que tenga más la caxa de plomo se puede ajustar a ella en el modelo en grande que es preçiso hazer para su execuçión [...] Porque, aunque la planta y perfil < de la nueva urna $>$

${ }^{40} \mathrm{Si}$ bien en la Capilla Real no puede jugar con la creación de una planta movida, como es el caso del Hospital de los Aragoneses, dada la escasez de espacio y planitud con la que cuenta. GARCÍA BAEZA, Antonio. La polifacética ..., op. cit., pp. 277-281.

${ }^{41}$ Francisco de Herrera el Mozo fue un afamado retablista, como ya lo reconocía Antonio Palomino (El parnaso español pintoresco laureado, tomo III. Madrid, 1724, pp. 412-415): «grandísimo arquitecto, y así hizo repetidas trazas para retablos y otras obras de arquitectura que oy las estiman los artífices, cada vna como una joya».

${ }^{42}$ HALCÓN ÁLVAREZ-OSSORIO, Fátima. «IV. El triunfo de la columna salomónica», en HALCÓN ÁLVAREZ-OSSORIO, Fátima; HERRERA GARCÍA, Francisco; RECIO MIR, Álvaro: El retablo sevillano: Desde los orígenes a la actualidad. Sevilla, 2009, pp. 205-211.

43 1671, octubre, 30. Madrid. Informe..., doc. cit. 
se pueda hazer ajustada para ejecutarla, no es bastante por los muchos degüellos de los que se compone, los quales no los puede dar la planta ni el perfil por ser yrregulares los vnos de los otros» ${ }^{44}$. Debiéndose valer «de arquitectura sin cornisa», es decir, abultada y fuera del encorsetamiento arquitrabado de un orden clásico, prácticamente anástila. Una decisión igualmente sostenida en el hecho técnico de que las «piezas de plata < por su brillo y claridad> encubren mucho sus suelos y es menester lebantar mucho sus remates para que se descuellen, en que se hallará mucho embarazo por lo limitado de su alto».

Para descanso del relicario, propone un pedestal a cuyo frente se inserta la «inscripçión de la veatificazión y nuevo culto, o de la canoniçazión» $\mathrm{y}$, en los laterales, los tres epitafios que se conservan desde antiguo. Finalmente, una novedad que contempla la traza, y que no prospera en los diseños futuros, es la inclusión de la espada Lobera dentro del banco de la urna, que cuenta con su propia tapa argéntea custodiada por dos llaves.

Resta aún una última advertencia por parte del pintor. Que el boceto es una especulación intuitiva a «falta de no ver el sitio, porque quatro dedos de sitio suelen ymportar en estas materias muchos y de vna misma traza se pueden hazer diferentes plantas en más o menos relieve conforme el sitio lo pidiere». Por lo que apela a una visita in situ o a la recepción de una planimetría más precisa para disponer el trazado definitivo ${ }^{45}$.

Para aprobar el proyecto, la Regente obliga al Arzobispo, al Visitador, al Cabildo y los capellanes a presentar su parecer ante la Cámara de Castilla, bien de manera individual, bien mancomunada, acompañada por el informe técnico de prestigiosos profesionales para los que Tejada propone los nombres de Ruesta como arquitecto, Bartolomé Esteban Murillo como pintor e «ynteligente en todo», y Diego de León como platero. Advirtiendo el canónigo que, de modo estratégico, se abaraten los costes de la obra casi a la mitad del total a fin de que en la Corte no se retraigan de su intención, dado que hasta la fecha el pecunio había sido el gran obstáculo a solventar.

Pero, sin duda, las anotaciones más interesantes del emisario atañen a la glosa de la figura de Herrera, del que indica que era de todos conocido cómo podía «conseguir por quatro, verbi gratia, lo que por ocho no se auía de hazer tan bueno». Y que el maestro se había ofrecido, si era necesario, a ejecutar en relieve los modelos para los bronces y para el sepulcro. E incluso a labrar las piedras y jaspes, «que en todos estos géneros es ygual su ynteligencia y manejo y su zelo de seuillano, pues se ofreçe ir a esta obra a Seuilla». Dando a conocer con sus palabras la elevada estima con la que el hispalense cuenta en Palacio.

En consecuencia, el emisario solicita a las cuatro partes implicadas que «ynformen a su magestad lo mucho que ymportará que don Francisco de Herrera su

\footnotetext{
${ }^{44}$ Ídem, f. [1v].

45 1671, octubre, 30. Madrid. Informe..., doc. cit., f. [1v].
} 
puesto que a hecho los deseños y que su yntleigençia y abilidad es tan general para todo lo que esta obra neçesita ${ }^{46}$. Un estratégico movimiento con el que la curia de Sevilla se convierte en la impulsora definitiva de la candidatura del artista en la Corte.

El primer día de diciembre los miembros de la Capilla Real se hacen eco de la noticia que anuncia la llegada de los diseños por mediación del visitador ${ }^{47}$. $« Y$, aviendo oydo el Cabildo y visto el caxón en que venían que estava sobre la mesa de la secretaría, <se> acordó que yo, el infraescripto <secretario Juan Fernando Farfán de Vera $>$, vaya en nombre de la Capilla a ver al señor Capellán Mayor y diga $<1 \mathrm{lo}>$ que se sirva de mandar». Quedando la caja reservada, en el ínterin, dentro de los muros de la institución bajo llaves custodiadas por dicho sacerdote ${ }^{48}$. Para cuando el baúl se abre y los capellanes reales extraen los distintos bastidores, se pudo comprobar a simple vista la preferencia cortesana por los dibujos herrerianos, ya que venían subrayados por marcos de tafetán colorado y rubricadas al pie ${ }^{49}$.

Fieles a las indicaciones reales, la entidad encarga al padre Gabriel Fontanar la búsqueda y asistencia del grupo de eminentes artistas que deben evaluar los trabajos $^{50}$. A dicha inspección concurren el día 13 del mismo mes en la capilla regia «Pedro Roldán, Francisco Rodríguez Escalorona (sic), Bernardo Simón de Pineda, maestros de escultor, de cantería de piedra, jaspe y arquitectos; y así mismo, Diego de León, maestro de platería y metales» ${ }^{51}$. Ni rastro de Ruesta ni de Murillo. Ausencias que en el caso del mareante se entiende lógica, en tanto que su propuesta había sido desechada. Y que, en el caso del pintor, se podría proponer como una muestra más de su literaria enemistad con el Mozo -tantas veces enarbolada por la historiografía-, pero que entendemos que es resultado, más bien, de un contexto más amplio en el que Pineda y Roldán -como parte del equipo catedralicio desde la elevación del triunfo o simulacro fernandino ${ }^{52}-$ se postulan con este

${ }^{46}$ [1671, octubre]. Madrid. Informe..., doc. cit., ff. [1v]-[2v].

47 1671, diciembre, 1. Sevilla. Capítulo. ACS, Capilla Real, Autos Capitulares, lib. 6, ff. $20-20 \mathrm{v}$.

48 1671, diciembre, 4. Sevilla. Capitulo. ACS, Capilla Real, Autos Capitulares, lib. 6, f. $20 \mathrm{v}$.

49 [1671, octubre]. Madrid. Informe de Juan de Tejada que acompaña a diseños de urna y retablo remitidos a la Diputación del Santo Rey. ACS, Varios VIII, San Fernando, legajo 10.735, f. $[1 \mathrm{v}]$.

50 1671, diciembre, 7. Sevilla. Capitulo. ACS, Capilla Real, Autos Capitulares, lib. 6, ff. $21-21 \mathrm{v}$.

51 1671, diciembre, 16. Sevilla. Informe de artistas sevillanos sobre los diseños remitidos desde la Corte. ACS, Varios VIII, San Fernando, legajo 10.739, expediente 9, f. [1].

${ }_{52}$ Así, a ambos se le encarga el peritaje del grabado del adorno de la Capilla Real que había realizado Juan de Gradilla frente a otro que había compuesto Murillo del mismo tema. 1671, octubre, 10. Capitulo. ACS, Capilla Real, Autos Capitulares, lib. 6, f. 16v. 
gesto ante Mariana de Austria como los artífices locales más adecuados para la ejecución de la obra ${ }^{53}$.

El peritaje de los maestros consistirá en la elección de las trazas más adecuadas para la urna y el tabernáculo teniendo en cuenta su fortaleza estructural, la adecuación al espacio, y la tasación pecuniaria y temporal de su hechura: venustas, firmitas y vanitas. Como viene marcado de Palacio, Pineda, Roldán y Rodríguez Escalona seleccionan los diseños de Herrera «por ser $<$ los $>$ más adequados al intento, de más nouedad y primor, y agradable hermosura. Y, auiéndolos atentamente visto y notado sus partes, medido y reconosçido su disposiçión, de acuerdo de todos quatro, voluemos a afirmarnos en dicho tanteo y aprecio echo por auernos parecido a nuestro leal sauer y entender más conforme a raçón, mirándo le con distinción cada una de sus partes conforme a su materia y forma.

«Y costará en lo que toca a la arquitectura, talla, escultura, embutidos, conducciones y máquinas, todo lo tocante a pidras de jaspe - 30.000 pesos de plata. Y, en quanto a la fortificaçión y seguridad de la fábrica de dicha capilla, nos pareçe no recibir daño, antes aiudará su fortificación por ser la materia más firme». Más en plata y bronce «poniendo en forma y perfecçión cada cosa en su lugar (como lo demuestran los deseños) en consideraçión de todo lo que ha de ser dorado de molido, sincelados y reparados, así en plata como en bronçe, talla, escultura y demás follajes». Lo que supone otros 850 marcos.

No obstante, consideran que, además de lo proyectado, debería disponerse una caja de cristales con perfiles de plata que sirva tanto para la exhibición de la reliquia en las jornadas señaladas como para su preservación diaria. Elevándose la cifra otros 1.100 marcos de plata y ascendiendo el total - con los adornos, sobrepuestos e imágenes de San Isidoro y San Leandro- a un monto de 89.600 pesos y 6 años de trabajo ${ }^{54}$.

Prelado, capellanes reales, capitulares y visitador de la Capilla refrendan los diseños del maestro Herrera entre el 10 y el 12 de enero de 1672, haciendo coincidir el envío de sus respuestas y de los informes técnicos en tiempo y forma con intención de dejar patente que se trata de una decisión mancomunada ${ }^{55}$. Ya en la

${ }^{53}$ [1672, enero, 12]. Sevilla. Esbozo de carta del Cabildo de la Catedral de Sevilla aprobando las trazas de Francisco de Herrera. ACS, Varios VIII, San Fernando, legajo 10.739, expediente 1.

${ }^{54}$ Este grupo de profesionales emitieron, al menos, dos copias del mismo informe destinadas al Deán y Cabildo Eclesiástico - que es novedad de este trabajo (1671, diciembre, 16. Sevilla. Informe..., doc. cit., ff. [1]-[1v])- y otra a la Capilla Real-recogido y transcrito por Sancho Corbacho ("Historia...", op. cit., pp. 102-103) y con fecha de 22 de diciembre-. Suponemos que se realizarían otras dos copias destinadas al visitador y al arzobispo.

55 1672, enero, 12. La Posada. Carta de Miguel de Arortegui y Echazarreta a Andrés de León Ledesma. ACS, Varios VIII, San Fernando, legajo 10.739, expediente9. Los refrendos de los capellanes y capitulares vienen contemplados en sus actas: 1671, diciembre, 23 y 1672, enero, 9. Sevilla. Capítulos. ACS, Capilla Real, Autos Capitulares, lib. 6, ff. 
Corte, Juan de Tejada recepciona las cartas y las entrega en mano a Íñigo Fernández del Campo ${ }^{56}$, Secretario del Patronazgo Real recientemente nombrado y responsable directo de la causa por la Reina Regente, a fin de hacerse eco de la petición de los canónigos de nombrar un interlocutor que «ajuste, asegure $y$ gouierne» en todo momento las obras que se lleven a cabo en "tan venerado sanctuario» ${ }^{57}$.

Pronto la realidad pone freno a las decorosas pretensiones de la Capilla Real y, tras la excitación inicial, la cuestión económica hace aparcar el proyecto a la espera de una coyuntura más favorable; diluyéndose las obligaciones contraídas, por una y otra parte, en un cúmulo de buenas intenciones. No en vano, para mantener vivo el proceso a bajo coste, desde Sevilla se propone dar los primeros pasos para la separación de los cuerpos incorruptos del Santo, su hijo y su esposa. Un trámite de obligado cumplimiento que se convierte en un acto constantemente reivindicado por capellanes reales ${ }^{58}$. Al respecto, la Capilla eleva una pregunta al arzobispo, al deán, al visitador y a la regente sobre la pretendida desunión del osario, dejando patente ante la Reina «la pobresa que padece <la institución> para que su magestad se sirva de haser aumento a sus cortas rentas» ${ }^{59}$.

A fin de mantener la independencia del culto del Santo y abaratar los trabajos, la institución pondera la posibilidad de reubicar los restos de Alfonso X y Beatriz de Suabia en el presbiterio, dentro de los dos nichos del frente, contenidos en el perímetro de las barandas ${ }^{60}$. Y mantener a Fernando III en su localización original, «por no averle en la Capilla tan reverente, tan condecorado, ni tan a propósito para altar separado del Santo Rey, y ser el primer lugar de la capilla el que ocupa oy y en el que quiso tener sepultado el Santo frente de la imagen santísima María, la reina de los reyes, su singular devota. Y, para que esté más eleuado, se levanta el pedestal sobre el que descansan las tres tumbas y caxas, todo lo que fuese

21v-22v (documento recogido con anterioridad por SANCHO CORBACHO, Heliodoro: "Historia...", op. cit., p. 115); 1672, enero, 12. Sevilla. Cabildo extraordinario. ACS, Archivo Capitular, Secretaría, Autos Capitulares, lib. 71, f. 3v; [1672, enero, 10]. Sevilla. Esbozo de la carta..., doc. cit.

56 1672, enero, 12. Sevilla. Cabildo..., doc. cit., f. 3v.

57 [1672, enero, 12]. Sevilla. Esbozo..., doc. cit., [s.f.].

58 1672, enero, 16. Sevilla. Capítulo. ACS, Capilla Real, Autos Capitulares, lib. 6, f. 22: Previamente ya se habían tomado medidas para la nueva ubicación de los cuerpos en los arcosolios de la entrada de la Capilla, habiéndose retirado sendos cuadros realizados para la fiesta del Santo con historias de Alfonso X y su madre, y que por «ser pintura mui ordinaria $i$ ser de mucha nota del pueblo» se reubican en la tribuna principal, más retirados del público.

59 1673, octubre, 27. Capítulo. ACS, Capilla Real, Autos Capitulares, lib. 6, f. 56v.

${ }^{60}$ 1673, noviembre, 11; 1673, noviembre, 18. Sevilla. Capítulos. ACS, Capilla Real, Autos Capitulares, lib. 6, ff. 56v-57; 1674, febrero, 8. Sevilla. Capítulo. ACS, Capilla Real, Autos Capitulares, lib. 6, f. 61. 
necesario para igualarse al altar que oy tiene» ${ }^{61}$. Un nuevo planteamiento avalado por argumentos técnicos de Matías de Arteaga y Bernardo Simón de Pineda que entienden que unir en una sola pieza sepulcro y retablo supondría un desagravio visual para con el resto de la estancia, una confusión entre las dos devociones y la separación de los restos del monarca del ámbito en que quiso reposar, y donde ha sido venerado -con particulares intermitencias-desde su fallecimiento. Además de suponer un sobrecosto considerable e innecesario, dado que implica intervenir el muro para agrandar el arcosolio y variar los ornamentos circundantes. No en vano, entendemos que en el fondo de este argumentario subyace el temor que tienen los capellanes a que, al reunir la imagen mariana y la reliquia real en un mismo retablo, se confundan ambas devociones y su culto se unifique. Disminuyendo con ello cuantiosamente el número de misas que pudieran surgir, con la consecuente reducción de regalías, prebendas y emolumentos que supondría.

Grabador y arquitecto proponen como alternativa al proyecto de Ruesta la permanencia de la distribución histórica de la cabecera en dos alturas con leves modificaciones, lo cual generaría una visión frontal del conjunto más armónica en la que el espectador pudiera encajar el sepulcro y el retablo en un solo golpe de vista y con proporción elegante. "De tal manera que, diciendo misa en ambos altares, desde qualquiera parte de la real capilla se vea y gozen. Y causan tal hermosura y agrado a la vista que por qualquier lado que se mire vno y otro. Magestuoso trono paresca que tiene todo vn enlaçamiento y vnión $\rangle^{62}$.

Este nuevo programa busca diferenciar con claridad los presbiterios alto y bajo. Prevé la elevación del histórico podio de la reliquia con un basamento de jaspe negro de un palmo de altura y la colocación de una peana en la parte superior del mismo de media vara y de la misma piedra, pero «color sangre y leche», con sobrepuestos de bronce dorado, cartelas, mecheros para luces y trabajos de intarsia. Lo que permitiría incorporar un altar fijo que anteceda al pedestal. Al ganar altura el sepulcro del Rey, los maestros se ven obligados a elevar la mesa de altar de la titular, proponiendo la realización de una grada de cuatro escalones que la anteceda. Y, como nexo entre ambos presbiterios, imaginan la colocación de una doble escalinata, cuyas paredes perimetrales - que hacen de forillo al relicario-se cubrirían por placas de jaspe, un material que tendría eco en las nuevas jambas del panteón real ubicadas en los laterales. Esta subida estaría recorrida por una barandilla de cedro dorado con apliques de bronce. Antepecho que se transformaría en labor de metalistería en el perímetro del presbiterio y el féretro

${ }^{61} 1673$, noviembre, 26. Sevilla. Capítulo. ACS, Capilla Real, Autos Capitulares, lib. 6, f. $57 \mathrm{v}$.

62 1674, mayo, 7. Sevilla. Informe de Matías de Arteaga y Bernardo Simón de Pineda sobre la ubicación de la urna de San Fernando. ACS, Varios VIII, San Fernando, Legajo 37 (7), expediente 5, f. [1v] (recogido previamente en QUILES GARCÍA, Fernando: «En los cimientos...», op. cit., p. 219, nota 80). 
real, donde disminuiría su tamaño hasta una altura de vara y cuarta para no perjudicar la contemplación del cuerpo y de la Eucaristía ${ }^{63}$.

En este proyecto, también se contempla la creación de un sepulcro-relicario diferente al herreriano. Un mueble sencillo con alma de cedro y cubrición argéntea, «matiçadas algunas pieças con sobredorado para más adorno i hermosura». Todo el perímetro de la pieza estaría recorrido por columnas de ébano revestidas de plata calada que cuentan con perfiles laterales que permiten introducir vidrios. Delante de los cuales se dispondrían puertas abatibles cerradas por cuarterones de lapislázuli con aplicaciones de oro y orlas de cristal dulce pintado. La cara frontal del relicario se prevé practicable, atendiéndose así a la conservación, visualización y fácil extracción del cuerpo que se encontraría en el interior dentro de la urna de plomo original, enfundado en seda sobredorada y dispuesto sobre una almohada de brocado. El joyero de plata descansaría sobre varias garras y se remataría con un penacho angélico portando los instrumentos gloriosos del finado ${ }^{64}$. "Para más autoridad y grandeça toda esta urna puede estar cubierta con un pabellón de tela para resguardo a la plata de el tiempo y sus humedades». Todo lo cual se comprometen darlo por concluido antes de la fiesta del Santo de $1675^{65}$.

Este cambio de planes en principio no es bien recibido en la Corte, pero con los años la idea irá suscribiendo adeptos y muchos de los conceptos que se proponen terminarán por incorporarse a la trama definitiva de la Capilla. Por el momento, Mariana de Austria y sus súbditos siguen apostando por reunificar reliquia y Theotokos en un único retablo. De modo que, a fin de aparcar posibles suspicacias y desvíos del proyecto de Herrera, la Regente llama al orden a la curia hispalense apelando a que corroboren los planes previstos ${ }^{66}$. Y es que, como manifiesta Fernández del Campo, para Palacio lo más acertado sigue siendo «poner al Santo a los pies de Nuestra Señora y, luego, bajar vn poco el altar y correr las gradas todas de pared a pared, como las del altar mayor, que sería de losa grande», tal y como «en León está San Isidro a los pies del Santísimo y no es inconueniente» ${ }^{67}$.

${ }^{63}$ 1674, mayo, 7. Sevilla. Informe..., doc. cit., f. [2]; [1674]. Sevilla. Informe de Bernardo Simón de Pineda sobre dos diseños para la urna de San Fernando y la reforma del presbiterio de la Capilla Real. ACS, Gobierno, Asuntos despachados, legajo 9.783, expediente 4, ff. [1]-[1v].

${ }_{64}$ 1674, mayo, 7. Sevilla. Informe..., doc. cit., f. [1v] y [1674]. Sevilla. Informe..., doc. cit., ff. [1]-[2]. Este último documento refiere varios esbozos realizados sobre el sepulcro ideado.

65 1674, mayo, 7. Sevilla. Informe..., doc. cit.

${ }_{66}$ 1674, mayo, 8. Madrid. Carta de Juan de Tejada remitiendo a la Diputación del Santo Rey el parecer de la Reina sobre la separación de los cuerpos reales. ACS, Varios VIII, San Fernando, legajo 10.739, expediente 9.

${ }_{67}$ 1674, junio, 4. Madrid. Carta de Juan de Tejada a la Diputación del Santo Rey sobre la separación de los cuerpos reales. ACS, Varios VIII, San Fernando, legajo 10.739, expediente 9. Esta falta de acuerdo entre la Corte y la Iglesia de Sevilla sobre la ubicación definitiva de los restos de 
La definitiva ubicación de los restos reales aún será motivo de veladas disputas entre Madrid y Sevilla durante largo tiempo. Por ello, con objeto de apaciguar los ánimos, los esfuerzos vuelven a concentrarse en la desunión de los cuerpos ${ }^{68}$, labor que se apremia con insistencia desde el Consejo de Castilla ${ }^{69}$. Con todo, incluso la celebración de este nimio trámite se convierte en objeto de disputa entre Palacio, que aboga por una celebración pública del acto de segregación, y los capellanes reales, que se oponen a ello aduciendo la incapacidad para acometer el acto sin la ayuda económica necesaria. Y es que aún siendo un acto privado el gasto se estima en 2.500 pesos $^{70}$. La decisión final es salomónica: la separación de los cuerpos regios se deberá llevar a cabo en la más estricta intimidad, pero contando con la asistencia de los munícipes y autoridades civiles ${ }^{71}$.

Fecha de recepción: 13 de septiembre de 2015.

Fecha de aceptación: 20 de noviembre de 2015.

San Fernando y la necesidad de ponerle una solución sigue latente en 1674, julio, 16. Sevilla. $C a$ pítulo. ACS, Capilla Real, Autos Capitulares, lib. 6, ff. 65v-66.

68 1674, junio, 6. Madrid. Carta de Fernández del Campo al Deán y Cabildo de la Catedral de Sevilla haciendo saber que se despacha una Cédula Real para la separación de los cuerpos reales. ACS, Varios VIII, San Fernando, legajo 10.739, expediente 9.

69 1674, julio, 3. Madrid. Carta de Juan de Tejada a la Diputación del Santo Rey sobre la impaciencia del Consejo de la Cámara ante la espera del informe de la separación de los cuerpos. ACS, Varios VIII, San Fernando, legajo 10.739, expediente 9 (recogido previamente en QUILES GARCÍA, Fernando: "En los cimientos...", op. cit., p. 222).

70 1674, julio, 7. Alcobendas. Carta de Jerónimo de Aranda y Guzmán a la Diputación del Santo Rey sobre la necesidad de no realizar el traslado de los cuerpos en acto público. ACS, Varios VIII, San Fernando, legajo 10.739, expediente 9.

71 1674, agosto, 14. Madrid. Carta de Juan de Tejada a la Diputación del Santo Rey sobre la asistencia del Cabildo Municipal de Sevilla a la separación de los cuerpos. ACS, Varios VIII, San Fernando, legajo 10.739, expediente 9.

1674, noviembre, 13. Capítulo. ACS, Capilla Real, Autos Capitulares, lib. 6, f. 72: Recepción de la Cédula Real por la que se permite separar los cuerpos. 1674, noviembre, 15. Capítulo. ACS, Capilla Real, Autos Capitulares, lib. 6, f. 72: Comienzan a prepararse los arcosolios que acogerán definitivamente a los cuerpos reales. 


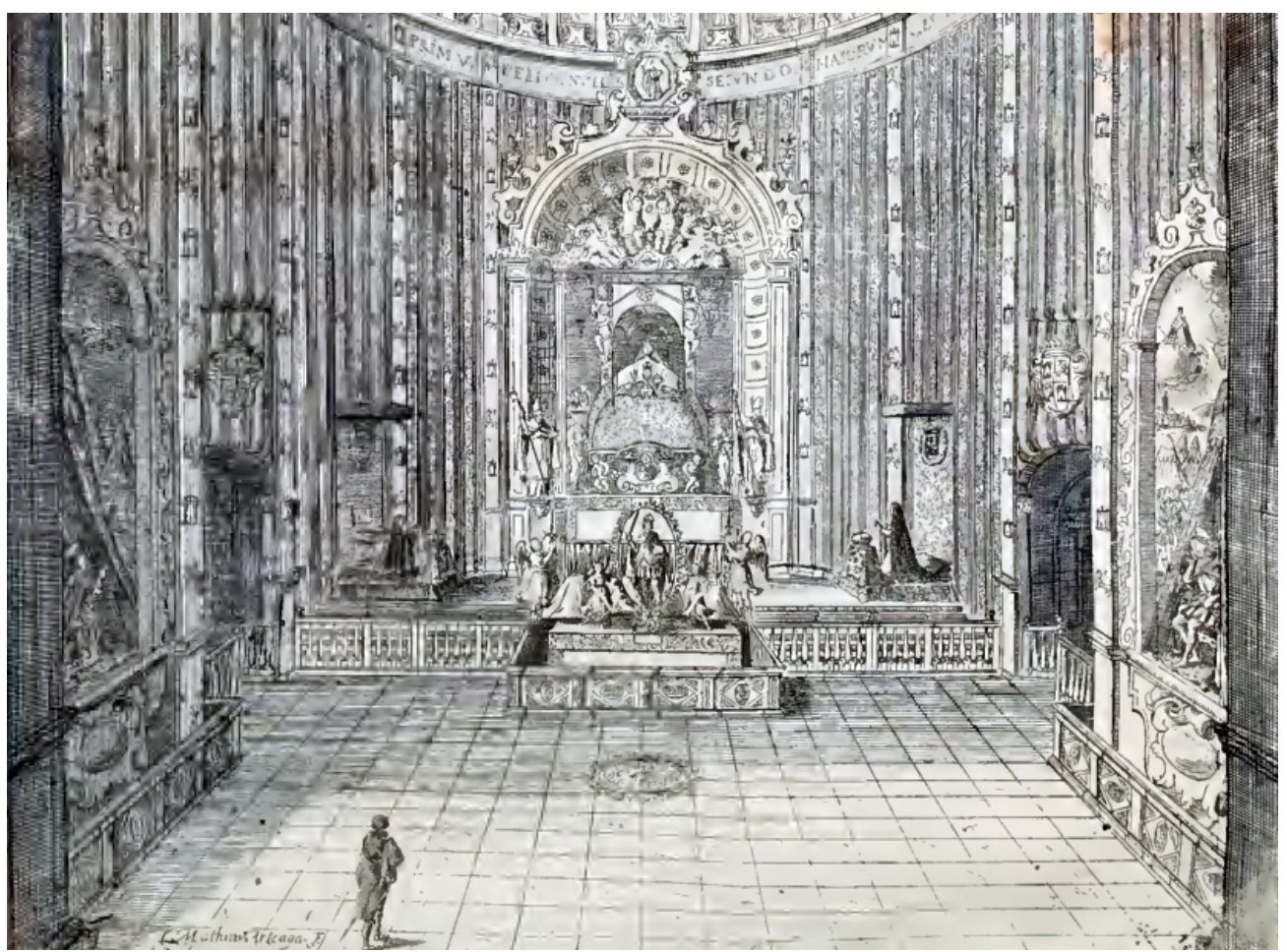

Figura 1. Capilla Real decorada para los fastos de Fernando III (detalle), Matías de Arteaga, 1671. 